\title{
Unexpected coronary arterial calcification and thrombosis late after Kawasaki disease
}

\author{
Niall Johnston, ${ }^{1}$ Aisling Snow, ${ }^{2}$ Colin J McMahon ${ }^{1,3}$
}

${ }^{1}$ Department of Cardiology, Our Lady's Children's Hospital, Crumlin, Dublin, Ireland ${ }^{2}$ Department of Radiology, Our Lady's Children's Hospital, Crumlin, Dublin, Ireland ${ }^{3}$ University College Dublin Dublin, Ireland

\section{Correspondence to} Dr Niall Johnston, nijohnst@gmail.com

Accepted 24 June 2016

\section{(1) CrossMark}

To cite: Johnston $\mathrm{N}$ Snow A, McMahon CJ. BMJ Case Rep Published online: [please include Day Month Year] doi:10.1136/bcr-2016216451

\section{DESCRIPTION}

A 14 year-old boy, with previous Kawasaki disease and coronary artery aneurysms, presented to hospital with severe angina-like chest pain which occurred suddenly while at rest. There was associated pallor, sweating and nausea. Symptoms lasted 1 hour. Initial investigations revealed negative cardiac enzymes and normal ECG. Initial chest radiograph demonstrated an ovoid area of calcification projected over the left side of the heart. CT imaging confirmed the presence of calcification of the left coronary aneurysm (figure 1). Selective angiography demonstrated a giant calcified left main coronary aneurysm with thrombosis and retrograde filling of the distal left anterior descending coronary artery via collateral vessels (figure $2 \mathrm{~A}$ ). A giant right coronary aneurysm with associated severe stenosis was also visualised (figure $2 \mathrm{~B}$ ).

The patient underwent successful coronary bypass grafting 5 days later (left internal mammary to distal left anterior descending artery, and right internal mammary to distal right coronary artery). Postoperative echocardiography revealed normal biventricular systolic function.

Kawasaki disease is the most common cause of acquired heart disease in childhood. ${ }^{1}$ Coronary artery aneurysms may develop in up to $20 \%$ of untreated children. Risk factors include male sex, extremes of age, elevated white cell count, and persisting fever despite treatment. ${ }^{2}$ In $1 \%$ of cases, aneurysms are 'giant' $(>8 \mathrm{~mm})$. Given the

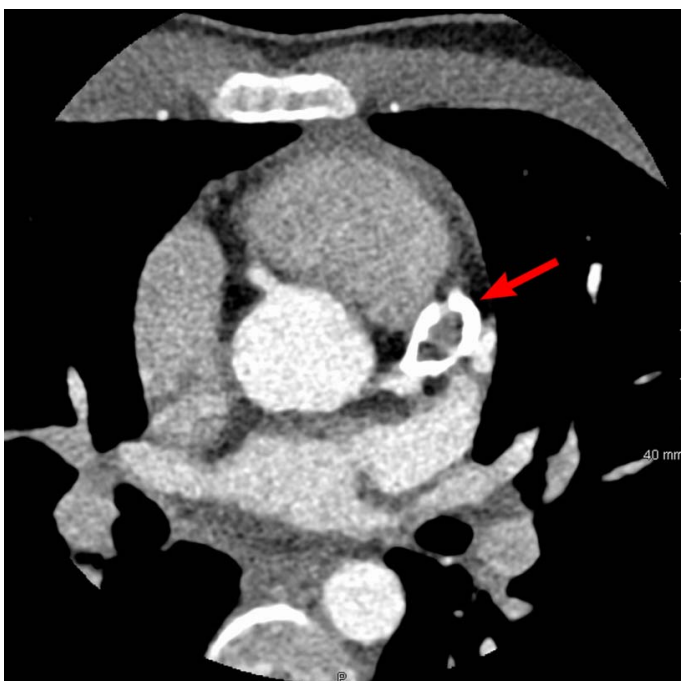

Figure 1 CT coronary arteries. Red arrow shows calcification of left coronary aneurysm.
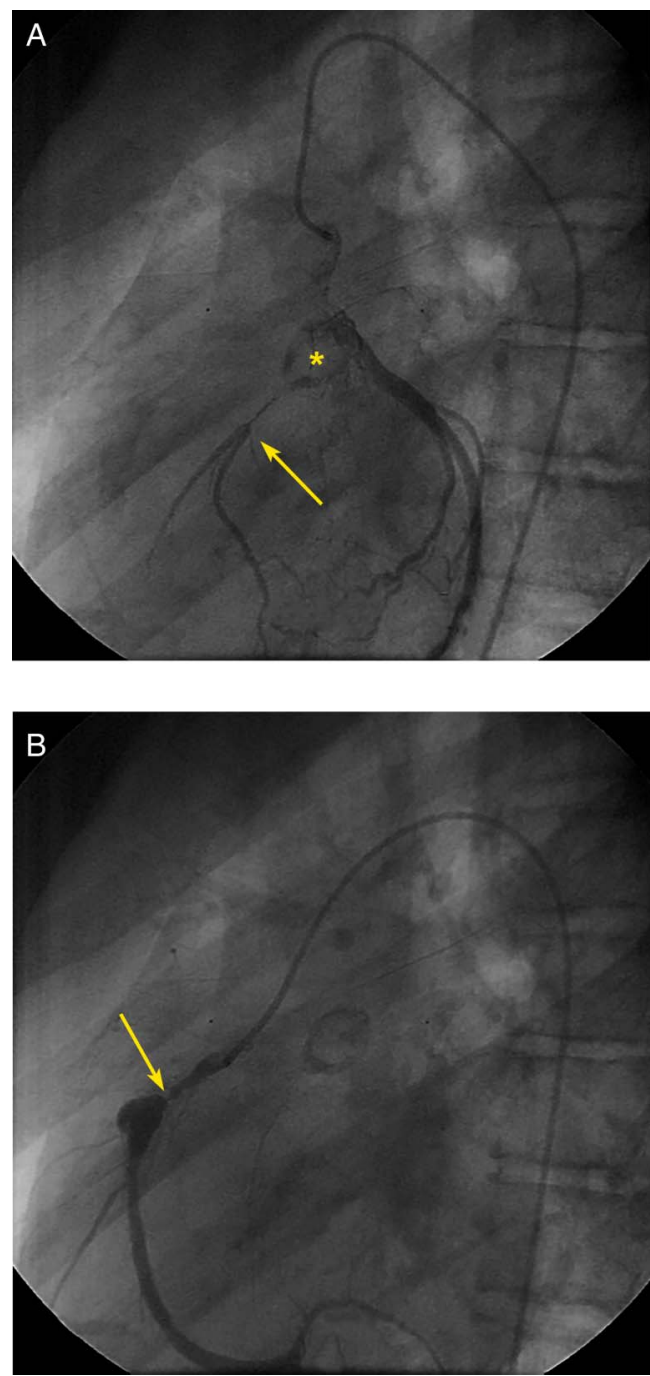

Figure 2 (A) Selective left coronary artery angiogram (lateral view) demonstrating thrombosis of the calcified aneurysm (asterisk) and retrograde filling of the distal left anterior descending coronary artery via collateral vessels (arrow). (B) Selective right coronary artery angiography (lateral view) showing the severe stenotic segment of right coronary artery (arrow) prior to the coronary arterial aneurysm.

significant risk of thrombus formation, antiplatelet and anticoagulation therapies are required. ${ }^{3}$ Symptomatic patients should also be considered for revascularisation procedures such as coronary artery bypass grafting. Modifiable risk factors, such as dyslipidaemia, elevated blood pressure, smoking and obesity, should be carefully addressed. 


\section{Learning points}

- Kawasaki disease is the most common cause of acquired heart disease in children, and may result in coronary aneurysms in nearly $20 \%$ of untreated cases.

- Giant coronary aneurysm may be complicated by calcification, thrombosis, and even rupture. Coronary artery anatomy is best visualised with CT imaging and selective coronary angiography.

- Symptomatic patients with giant coronary aneurysms require antiplatelet therapy, anticoagulation, and often revascularisation procedures. Close follow-up is warranted.
Acknowledgements The authors thank Mr Andrew Pendred for preparing the images for publication.

Contributors CJM identified and managed the case. AS provided imaging. NJ was responsible for manuscript preparation. CJM, AS and NJ were involved in producing the final manuscript.

Competing interests None declared.

Patient consent Obtained.

Provenance and peer review Not commissioned; externally peer reviewed.

\section{REFERENCES}

1 Maconochie I. Kawasaki disease. Arch Dis Child Educ Pract Ed 2004;89:ep3-8.

2 Scuccimarri R. Kawasaki disease. Pediatr Clin N Am 2012;59:425-45.

3 Eleftheriou D, Levin M, Shingadia D, et al. Management of Kawasaki disease. Arch Dis Child 2014;99:74-83.

Copyright 2016 BMJ Publishing Group. All rights reserved. For permission to reuse any of this content visit

http://group.bmj.com/group/rights-licensing/permissions.

BMJ Case Report Fellows may re-use this article for personal use and teaching without any further permission.

Become a Fellow of BMJ Case Reports today and you can:

- Submit as many cases as you like

- Enjoy fast sympathetic peer review and rapid publication of accepted articles

- Access all the published articles

- Re-use any of the published material for personal use and teaching without further permission

For information on Institutional Fellowships contact consortiasales@bmjgroup.com

Visit casereports.bmj.com for more articles like this and to become a Fellow 